University of Nebraska - Lincoln

DigitalCommons@University of Nebraska - Lincoln

U.S. Environmental Protection Agency Papers

U.S. Environmental Protection Agency

2001

\title{
A Practical Guide to Estimating Cleanup Costs
}

Mike Goldstein

United States Environmental Agency

Jon Ritterling

URS Corporation in Omaha, Nebraska

Follow this and additional works at: https://digitalcommons.unl.edu/usepapapers

Part of the Civil and Environmental Engineering Commons

Goldstein, Mike and Ritterling, Jon, "A Practical Guide to Estimating Cleanup Costs" (2001). U.S. Environmental Protection Agency Papers. 30.

https://digitalcommons.unl.edu/usepapapers/30

This Article is brought to you for free and open access by the U.S. Environmental Protection Agency at DigitalCommons@University of Nebraska - Lincoln. It has been accepted for inclusion in U.S. Environmental Protection Agency Papers by an authorized administrator of DigitalCommons@University of Nebraska - Lincoln. 


\title{
A Practical Guide to Estimating Cleanup Costs
}

\author{
Mike L. Goldstein • Jon M. Ritterling
}

Mike L. Goldstein is an environmental scientist with the U.S. Environmental Protection Agency, Region 10. He has two years experience as a project manager of Superfund cleanup and eight years experience as a technical policy analyst at EPA beadquarters, in Washington, DC. His areas of expertise include radiation site cleanup, Superfund remedy selection policy and guidance, and cost estimating.

Jon M. Ritterling, PE, is a senior civil/environmental engineer and project manager with the URS Corporation in Omaba, Nebraska. He bas ten years experience in environmental restoration projects. His areas of technical expertise include contaminant fate and transport, feasibility analysis of remedial alternatives, remedial design/optimization, and cost estimating.
Cost estimates are frequently developed to evaluate hazardous-waste-site cleanup options in support of a site investigation, remedy selection decision, or assessment of environmental liabilities. The accuracy of the cost estimate depends largely on the quality of the information available at the time it is prepared. This article presents a practical guide to developing a cleanup cost estimate. It includes information on how to document assumptions, use the latest technical resources, and perform basic adjustments to account for uncertainty and the time value of money. The content is based upon a recent guidance document issued by the U.S. Environmental Protection Agency and U.S. Army Corps of Engineers entitled A Guide to Developing and Documenting Cost Estimates during the Feasibility Study (USEPA, 2000). (C) 2001 John Wiley E Sons, Inc.

\section{INTRODUCTION}

A common complaint during environmental cleanup projects is that the actual costs rarely resemble the costs that were forecast at the beginning of the site investigation and remedy selection process. This often leads to the perception that the initial cost estimate was wrong. While there may be errors, the more common reason for this difference is that the project that was ultimately implemented differs from what was assumed or originally envisioned at the time of the initial estimate.

As shown in Exhibit 1, the accuracy of cost estimates improves as the project becomes more defined. Cost estimates based on limited information are typically developed early in the cleanup process, such as at the completion of a remedial investigation/feasibility study and during remedy selection. Although these preliminary estimates are typically qualified with a disclaimer that they should not be used for final project budgeting, the reality is that they frequently become the cornerstones for future cost-driven decisions. For example, initial estimates are often used as the basis for contract decisions, large legal settlements, and remedy selection decisions. 
Exhibit 1. Cost Estimate Accuracy vs. Project Phase

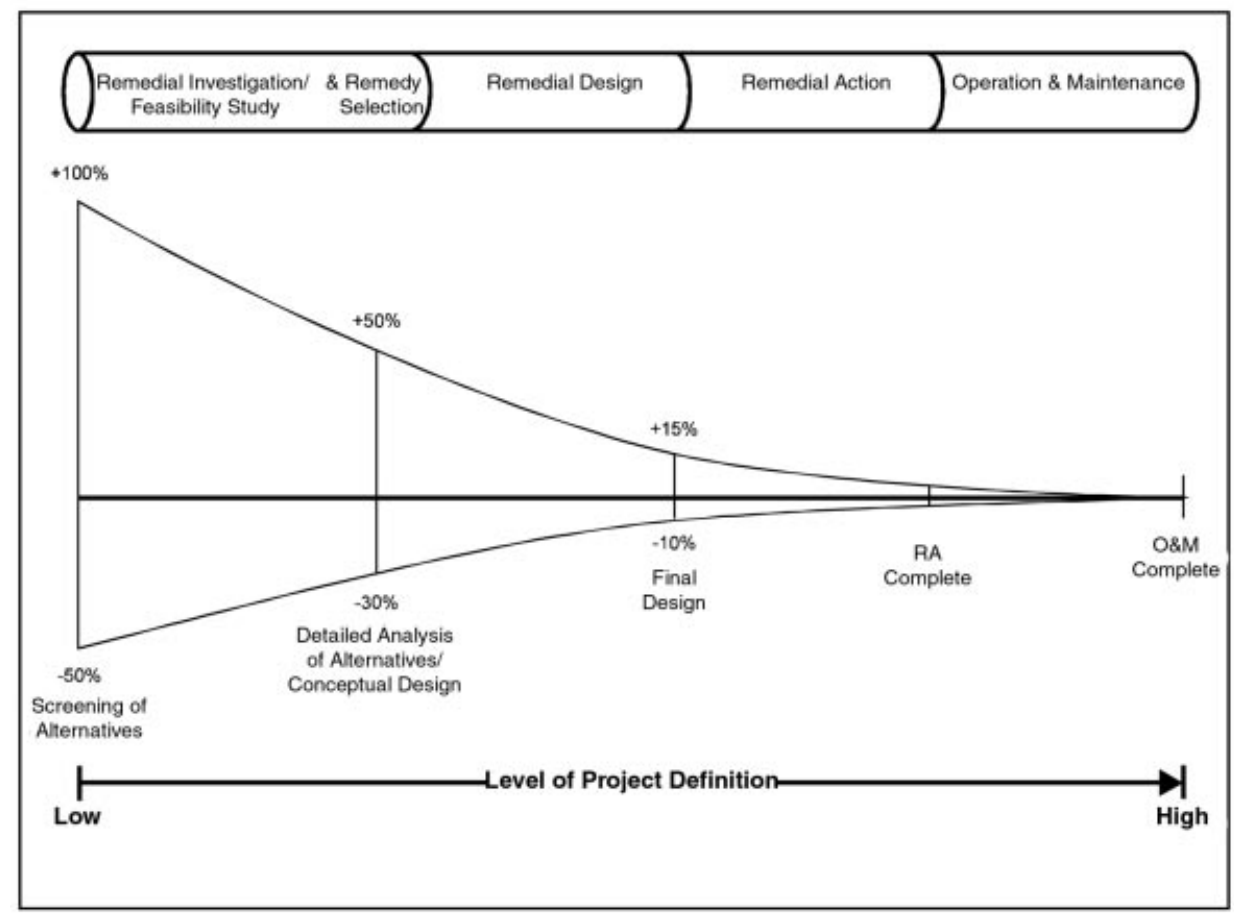

Developing a cost estimate early in the process with limited information is one of the most difficult tasks to perform well. The premise of this article is that "wrong" cost estimates occur because the project scope and/ or assumptions used to develop the estimate are often not well thought out or documented. The responsibility of a technical consultant, who may be asked to develop a cost estimate, is to estimate what activities will be necessary to perform the remedial action and then document assumptions and sources of cost information. A "correct" cost estimate is one that is defensible and reproducible. The steps presented below are designed to help develop more accurate and complete cost estimates using limited information.

\section{STEPS TO DEVELOP THE ESTIMATE}

The steps presented for developing a cleanup cost estimate follow an activity-based approach, in which the project is divided into discrete, quantifiable activities, which are then costed out. Each of these steps, which are presented as a flowchart in Exhibit 2, asks key questions that need to be answered to complete the estimate.

\section{Step 1: Estimate Activities and Schedule}

Before launching into a cost-estimating exercise, a series of key questions needs to be addressed regarding the scope of the project. For example: 
Exhibit 2. Steps to Develop a Cleanup Cost Estimate

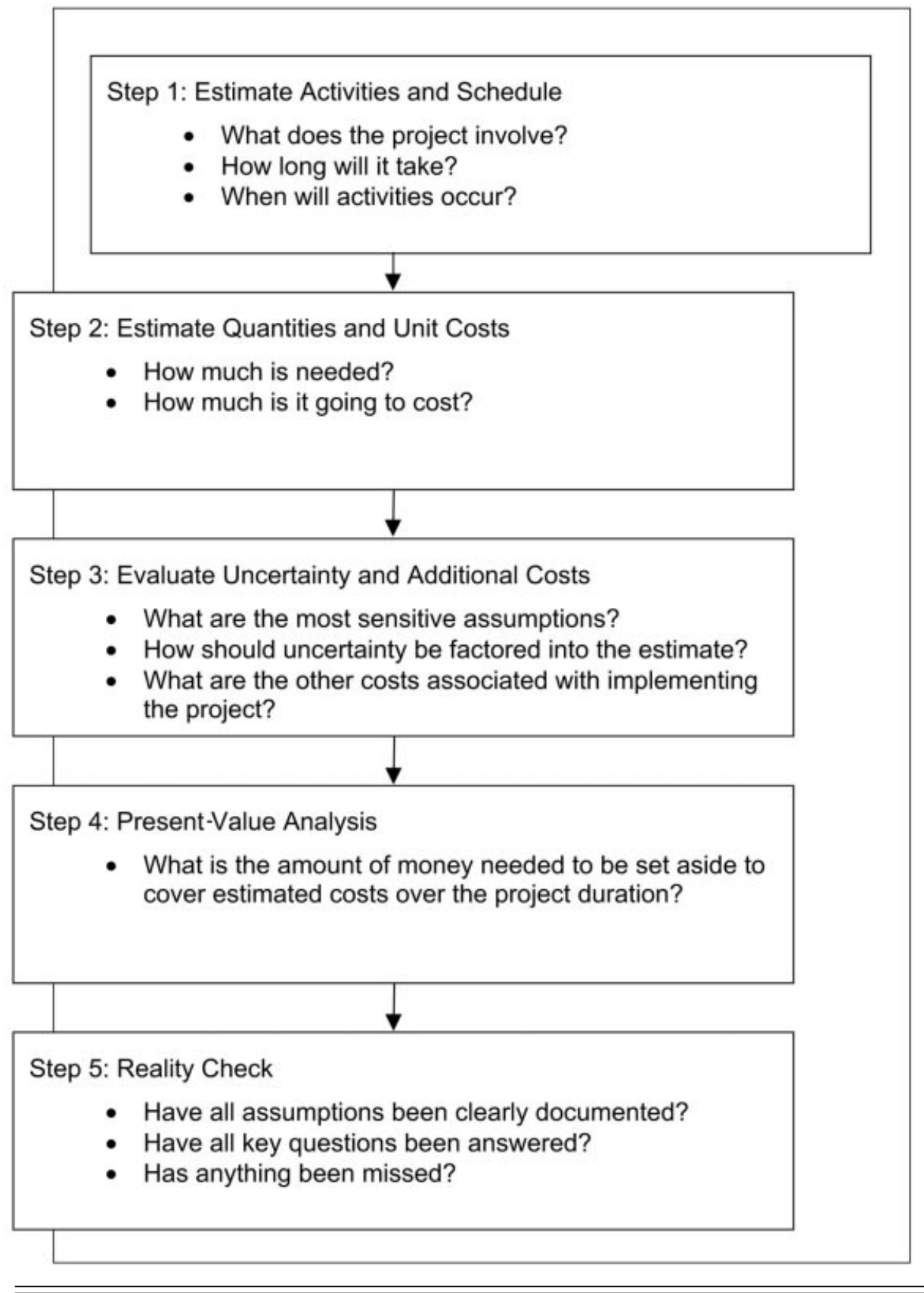

- What does the project involve?

- How long will it take?

- When will activities occur?

The quality of this information depends on where the project is in the cleanup process (see Exhibit 1). In general, there are more uncertainties 


\section{Exhibit 3. Impact of Project Definition on Cost Estimate}

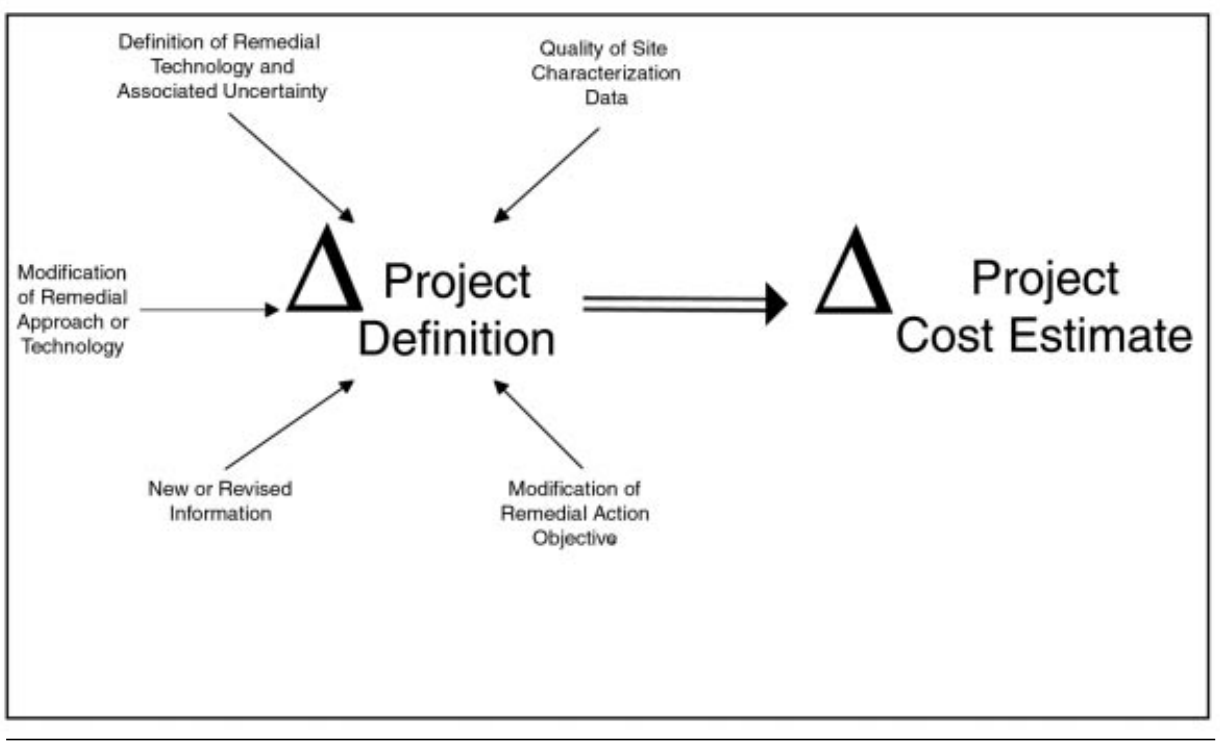

in project definition earlier in the process and less uncertainty farther along toward design and construction. Exhibit 3 illustrates the types of factors that can have a large impact on the project scope or definition, and thus on the project cost estimate as well.

Early in the cleanup process, a conceptual design must be generated for the project before a cost estimate can be developed. The conceptual design should be as specific as possible, generally more detailed than a design engineer would feel comfortable preparing given the amount of data available at this stage of the process. The conceptual design should also include a preliminary project schedule. The estimated duration, or total length, of the project must be identified so that a complete "life cycle" cost estimate can be developed for the project. The estimated duration is important for identifying activities that occur either annually or once every few years.

The first part of Step 1 is to write a project description to use as a guide through the cost-estimating process. The following is an example:

Alternative 3 consists of air sparging and soil vapor extraction to treat soil and groundwater contaminated with volatile organic compounds in the source area. It also includes a passive treatment wall along the leading edge of the plume to treat groundwater migrating off-site. It is assumed that construction will be completed within one year and that the required cleanup objectives will be achieved in 15 years. There will be annual operation and maintenance activities associated with the project as well as periodic tasks occurring in Years 5, 10, and 15.

Once the project description is completed, it is translated into a conceptual design. The conceptual design should be as specific as possible 
... any activities associated with implementing the cleanup should be identified and quantified during the cost-estimating process. so that an "activity-based" cost estimate can be developed. This means that any activities associated with implementing the cleanup should be identified and quantified during the cost-estimating process. It is helpful to organize activities into different categories based on when they will occur. For example, activities that are performed in the beginning of a project during initial construction and operation could be separated from those activities associated with the annual operation and maintenance (O\&M) of a functional remedy. Likewise, periodic activities occurring in "out-years," such as equipment replacement or cap replacement, can also be separated from the first two categories of work. It is recommended that activities be structured using the following three categories, in as much detail as possible:

Category 1-Initial Activities are construction activities that are associated with a remedial action project. They include activities associated with the initial startup and operation of a remedy, but do not include activities necessary to operate or maintain the remedy throughout its lifetime. The costs associated with these activities are generally called capital costs.

Category 2-Annual Activities are post-construction operation and maintenance activities necessary to ensure the continued effectiveness of a remedial action. The costs associated with these activities are generally called O\&M costs.

Category 3-Periodic Activities are those that occur only once every few years (e.g., remedy evaluations every 5 years, equipment replacement every 15 years) or only once during the entire duration of the project (e.g., site closeout, remedy failure/replacement). The costs associated with these activities can be considered either O\&M costs or new capital costs.

Developing and documenting an initial cost estimate in this manner is consistent with the way in which projects are managed and costs are reported in the field. For example, it is fairly common to award a construction contract to one contractor and award a contract for annual operations and maintenance work to a different contractor, especially for larger projects. This is due to the different types of expertise required to perform the duties associated with each phase of the project. An example of how activities could be identified and structured for a project is shown in Exhibit 4.

To help identify activities for a project, a series of cost element checklists are contained in Chapter 3 of $A$ Guide to Developing and Documenting Cost Estimates during the Feasibility Study (USEPA, 2000). These checklists are helpful during this first stage of the cost-estimating process. Engineering judgment should also be sought from individuals who have had experience with similar types of cleanup projects.

Technology databases can also be used to help identify project activities during the cost-estimating process. Many of these types of resources are available on the Internet. Several good Web sites include 


\section{Exhibit 4. Example of Activity-Based Conceptual Design}

\section{Initial Activities}

- Mobilization/Demobilization Construction Equipment and Facilities Submittals/Implementation Plans Temporary Facilities \& Utilities Post-Construction Submittals

- Monitoring, Sampling, Testing, and Analysis SVE Monitoring Wells Treatment Wall Monitoring Wells

- $\quad$ Site Work

Clearing and Grubbing Seeding/Mulch/Fertilizer

- Air Sparging/Soil Vapor Extraction Mobilize SVE System

AS Injection Wells

AS Blower

AS Piping

SVE System

SVE Extraction Wells

SVE Piping

Electrical Hookup

Startup and Testing

- Passive Treatment Wall

Construct Slurry Trench

Install Reactive Media

- Off-Site Treatment/Disposal

Off-Site Transport of Soil Cuttings

Off-Site Disposal of Soil Cuttings

Wastewater Discharge/Testing

- Project Management

- Remedial Design

- Construction Management

- Institutional Controls

Institutional Controls Plan

Groundwater Use Restriction

Site Information Database

\section{Annual Activities}

- Performance Monitoring

SVE Vapor Monitoring

SVE Emissions Monitoring

Treatment Wall_-Groundwater Sampling

Treatment Wall—Groundwater Analysis

- Site Monitoring

Groundwater Sampling

Groundwater Laboratory Analysis

- Air Sparging/Soil Vapor Extraction

Operations Labor

Maintenance Labor

Equipment Repair

Utilities

- Off-Site Treatment/Disposal

Wastewater Discharge/Testing

- Project Management

- Technical Support

- Institutional Controls

Site Information Database

\section{Periodic Activities}

- Comprehensive Remedy Reviews (once every five years as required by CERCLA)

- Demobilization of AS/SVE System (at completion of project)

- Well Abandonment (at completion of project)

- Remedial Action Report (at completion of project)

- Update Institutional Controls Plan (once every five years based on comprehensive remedy review) 
Hazardous Waste Cleanup Information (http://www.clu-in.org/), Federal Remediation Technologies Roundtable (http://www.frtr.gov/), and Remedial Technologies Development Forum (http://www.rtdf.org). A more complete list of Internet resources can be found in Appendix A of USEPA (2000).

\section{Step 2: Estimate Quantities and Unit Costs}

For Step 2, a couple of key questions to address for each identified activity are the following:

- How much is needed?

- How much is it going to cost?

\section{Estimate Quantities}

Now that a conceptual design has been articulated and major activities associated with the project have been described, the quantities of the various activities must be estimated. Some activities do not easily lend themselves to being quantified and therefore must be estimated as a lump sum.

The estimation of quantities is directly related to the quality and

Some activities do not easily lend themselves to being quantified ... quantity of site characterization data. For example, the estimated quantity of soil or groundwater that must be cleaned up to achieve a cleanup goal depends upon the data collected to determine the nature and extent of contamination. Likewise, the estimated soil vapor extraction rate or groundwater pumping rate depends on the methods used to estimate air permeability or hydraulic conductivity (e.g., estimated values based on soil type, field pumping tests), as well as the operating capacity of the equipment (e.g., sizing of pumps, blowers, etc.). Other factors can affect the quantity estimate, such as the expected "swell" or "fluff" in volume of excavated material for an ex-situ soil cleanup or the anticipated number of aquifer volumes to remove for an ex-situ groundwater cleanup.

Quantity calculations used to support a cost estimate should be adequately documented. Supporting information can include boring logs, chemical analysis results, and scaled drawings to show lateral and vertical extent of contamination and to estimate physical characteristics such as porosity and dry unit weight that affect the quantity estimate. Assumptions used to estimate quantities should be clearly presented.

Using the example shown in Exhibit 4, example quantities for initial activities would be the number of SVE monitoring wells, acres of clearing and grubbing, lineal feet of SVE piping, cubic yards of reactive media, etc. Example quantities for annual activities would be the number of groundwater sampling events for site monitoring, the number of months of operations labor for the AS/SVE system, etc.

\section{Estimate Unit Costs}

At this point, costs are assigned to specific activities (initial, annual, or periodic), consisting of either capital or O\&M costs. Unit cost data can be selected from a variety of sources, including 
Cost-estimating guides or references (e.g., unit price books) can provide costs for a wide variety of construction activities, including those related to site cleanup.
- Cost-estimating guides/references;

- Vendor or contractor quotes;

- Experience with similar projects; and

- Cost-estimating software/databases.

Cost-estimating guides or references (e.g., unit price books) can provide costs for a wide variety of construction activities, including those related to site cleanup. Some guides are specifically tailored to estimate costs for environmental remediation projects. Cost data in these references are sometimes broken down into labor, equipment, and material categories, and may or may not include contractor markups. Generally, each cost is associated with a specific labor and equipment crew and production rate. Costs are typically provided on a national average basis for the year of publication of the reference. Some of these guides or references are listed in Appendix A of USEPA (2000).

Quotes from vendors or construction contractors can provide costs that are more site-specific in nature than costs taken from standard guides and references. These quotes usually include contractor markups and are typically provided as a total cost rather than categorized as labor, equipment, or materials. If possible, more than one vendor quote should be obtained. Quotes from multiple sources can be averaged, or the highest quote can be used in the cost estimate if the collected quotes seem to be at the low end of the industry range. Vendors or contractors can also be an important source of design-related information, including operating capacity, production rates, operating life, and maintenance schedules that may impact O\&M costs.

Experience with similar projects, including both estimates and actual costs, can also be used as a source of cost data. Engineering judgement should be exercised if cost data from another project need to be adjusted to take into account site- or technology-specific parameters. Sources of actual cost data from government remediation projects are maintained by various federal agencies. These sources include the Historical Cost Analysis System (HCAS) (http://www.frtr.gov/cost/ec2/index.html) and Federal Remediation Technologies Roundtable (FRTR) cost and performance reports (http://www.frtr.gov/cost/). HCAS and the FRTR reports are two initiatives that are currently being used to collect and record treatment technology costs in a standardized format. Some of these sources of historical cost data are listed in Appendix A of USEPA (2000).

Cost-estimating software and databases can also be used as sources of cost data. The majority of available software tools are designed to estimate the cost for all or selected cost elements of an alternative. Governmentsponsored software tools include Micro Computer Aided Cost Engineering System (MCACES), which is used by the U.S. Army Corps of Engineers and is linked to the Unit Price Book (UPB) database (http:// www.hnd.usace.army.mil/traces/), and the Remedial Action Cost Engineering and Requirements (RACER), which is sponsored by the U.S. Air Force (http://www.talpart.com/products/racer/index.html). Some of these software or databases, both private and publicly sponsored, are listed in Appendix A of USEPA (2000). 


\section{Adjust Unit Costs}

The following types of adjustments should be made to unit cost data, if they are from different sources, so that they can be added into the project cost estimate:

- Apply productivity factors per health and safety level of protection

- Escalate costs to base year of estimate

- Apply area cost factors

- Add contractor markups

As the level of health and safety protection (e.g., personal protective equipment, monitoring requirements) is increased, productivity is decreased and costs are increased. For applicable cost elements, factors that reflect decreased productivity due to required health and safety levels of protection should be applied to labor and equipment costs. Unit costs that are obtained from sources that are one year old or more need to be updated or escalated to the base year, which is usually the current year. Area cost factors should be applied to unit costs from sources based on a national average (e.g., standard cost guides) or from other geographic locations (e.g., similar projects). More information on applying productivity, escalation, and area cost factors is provided in Appendix B of USEPA (2000).

Contractor markups, or overhead and profit, which may vary between activity costs, should be added. Markups include overhead and profit for

Overhead includes two main types: (1) job or field office overhead, also known as general conditions, and (2) home office overhead, also known as general and administrative $(G \& A)$ costs. the prime contractor and any subcontractors. Markups should generally be applied to the cost of individual activities, but, alternatively, can be applied to the total of those activity costs if the source of cost data for each is the same. Markups should not be duplicated or applied to costs that have already been "marked up."

The source of cost data can dictate how or if markups should be applied. For example, a vendor or contractor quote may include overhead and profit (i.e., "burdened"), whereas a unit price taken from a standard cost-estimating guide may not (i.e., "non-burdened"). Typically, costs taken from pricing guides need to have overhead and profit added.

Overhead includes two main types: (1) job or field office overhead, also known as general conditions, and (2) home office overhead, also known as general and administrative (G\&A) costs. Field office overhead can include costs for field supervision and office personnel, temporary facilities and utilities, telephone and communications, permits and licenses, travel and per diem, personal protective equipment, quality control, insurance, bond, and taxes. Home office overhead is the contractor's overall cost of doing business, as shared by the project. Profit is the return on the contractor's investment in the project. Generally, field office overhead can range from about 5 percent (for total project costs greater than $\$ 500,000$ ) to 25 percent (for total project costs less than $\$ 50,000$ ). Home office overhead is usually about 5 percent of total project cost. Profit typically ranges from 8 to 10 percent of total project cost.

An example of how a unit cost might be adjusted is shown in Exhibit 5 for construction cost of a soil vapor extraction well. 
Exhibit 5. Example Unit Cost Adjustment

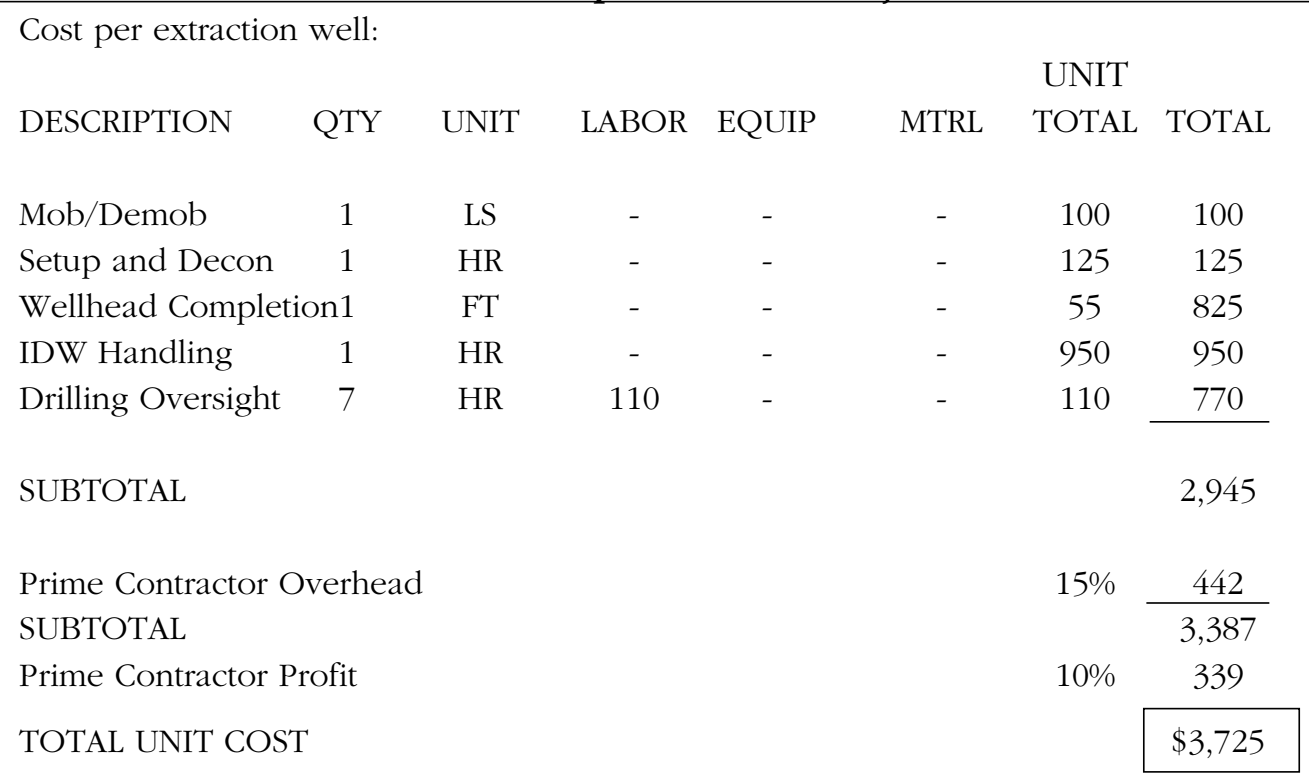

In this example, costs are based on a quote from a local drilling subcontractor, itemized by activity. The assumed health and safety level of protection is built into the quote; therefore, no outside adjustment is made for health and safety productivity. Likewise, no costs are escalated, because the base year is the current year, and no area cost factor is applied, because the quote is local. Subcontractor overhead and profit are included in the quote. Prime contractor overhead and profit are added. Unit prices taken from standard cost-estimating guides typically are broken down into labor, equipment, and materials categories. However, since these were not provided in the quote, these are not shown except for oversight, which is based on typical labor rates in the area for a geologist and technician.

Using the above example, if eight soil vapor extraction wells are to be installed, then the total cost of this activity would be $8 \times \$ 3,725=\$ 29,800$.

This unit cost can then be rolled into the cost for the individual activity, as shown in Exhibit 6, which illustrates the construction cost of an air sparging/soil vapor extraction system.

\section{Step 3: Evaluate Uncertainty and Additional Costs}

At this stage, quantities and costs have been estimated for individual activities, but there are a number of other items that should also be added to the estimate. This is padding to account for uncertainty and cost growth as well as a number of higher-level project-management-type costs that are associated with implementing the cleanup action and cannot be attributed to a single construction activity. Here are a couple of key questions to guide you through this step:

- What are the most sensitive assumptions?

- How should uncertainty be factored into the estimate? 
- What are the other costs associated with implementing the project?

\section{Uncertainty}

There are a number of ways to account for uncertainty in a cost estimate. A quantitative sensitivity analysis can be performed at the end of the estimating process. This sensitivity analysis could focus on those factors that have a relatively high degree of uncertainty and that, with only a small change in their value, could significantly affect the overall cost of the project. The results of a sensitivity analysis should be footnoted wherever the cost estimate is summarized, so that the project manager has a better appreciation for the uncertainty associated with the bottom-line number.

Another common method for factoring uncertainty into a cost estimate, which is recommended, is to apply a "contingency" cost. Contingency is factored into a cost estimate to cover unknowns, unforeseen circumstances, or unanticipated conditions that are not possible to evaluate from the data on hand at the time the estimate is prepared. It is used to reduce the risk of possible cost overruns.

For cost estimates performed early in a project's life cycle, contingency is typically applied as a percentage of the total cost, rather than applied to individual activities or line items (although this type of analysis would certainly be possible with more data). The contingency percentage can be based on engineering judgement for early cost estimates.

The two main types of contingency are scope and bid. Scope contingency covers unknown costs that may result from scope changes that may occur during design. Bid contingency covers unknown costs associated with constructing or implementing a given project scope.

Scope contingency represents project risks associated with an incomplete design. This type of contingency represents unforeseeable costs that are likely to become known as the remedial design proceeds. For this reason, scope contingency is sometimes referred to as "design" contin-

Exhibit 6. Example Calculation of Activity Cost

\begin{tabular}{|c|c|c|c|c|}
\hline \multirow[b]{2}{*}{ Air Sparging/Soil Vapor Extractio } & QTY & UNIT & $\begin{array}{l}\text { UNIT } \\
\text { COST }\end{array}$ & TOTAL \\
\hline & & & & \\
\hline Mobiliz SVE System & 1 & EA & $\$ 1,534$ & $\$ 1,534$ \\
\hline Impemeable Surface Cover & 105,000 & SF & $\$ 0.84$ & $\$ 88,200$ \\
\hline SVE Extraction Wells & 8 & EA & $\$ 3,725$ & $\$ 29,803$ \\
\hline AS Injection Wells & 2 & EA & $\$ 4,645$ & $\$ 9,290$ \\
\hline SVE System & 1 & EA & $\$ 93,510$ & $\$ 93,510$ \\
\hline AS Blower & 1 & EA & $\$ 5,712$ & $\$ 5,712$ \\
\hline SVE Piping & 400 & LF & $\$ 8.66$ & $\$ 3,464$ \\
\hline AS Piping & 100 & LF & $\$ 5.03$ & $\$ 503$ \\
\hline Electrical Hookup & 1 & LS & $\$ 9,898$ & $\$ 9,898$ \\
\hline Startup and Testing & 1 & LS & $\$ 10,936$ & $\$ 10,936$ \\
\hline SUBTOTAL & & & & $\$ 252,851$ \\
\hline
\end{tabular}


gency. In general, scope contingency should decrease as design progresses and should be 0 percent at the 100 percent design stage. A low scope contingency indicates that the project scope will undergo minimal change during design. A high scope contingency indicates that the project scope may change considerably between the feasibility study and final design. Scope contingency typically ranges from 10 to 25 percent. Higher values may be justified for alternatives with greater levels of cost growth potential.

Bid contingency represents unforeseeable costs that are likely to become known as the remedial action construction or O\&M proceeds. For this reason, bid contingency is sometimes referred to as "construction" contingency. Bid contingency accounts for changes that occur after the construction contract is awarded. This contingency represents a reserve for quantity overruns, modifications, change orders, and/or claims during construction. Considerations include the technological, geotechnical, and other unknowns applicable to the construction phase. Examples include changes due to adverse weather, material or supply shortages, or new regulations. Bid contingency typically ranges from 10 to 20 percent.

Bid and scope contingency may be added together and applied to the total of initial, annual, or periodic activities costs as shown in Exhibit 7 for initial construction costs.

\section{Additional Costs}

After contingency, there are still other costs that should be added into the estimate at this stage of the process. These are higher-level projectmanagement-type costs associated with implementing the cleanup action and are not attributed to a single construction activity. These costs are sometimes referred to as "indirect costs" or "the costs of professional and technical services." These costs should generally be estimated as a percentage of the total cost. The following are some examples:

- Project Management-Includes planning and reporting, community relations support during construction or O\&M, bid or contract

Exhibit 7. Example Contingency Application

Mobilization / Demobilization

Monitoring, Sampling, Testing, and Analysis

Site Work

Air Sparging / Soil Vapor Extraction

Passive Treatment Wall

Off-Site Treatment / Disposal

SUBTOTAL

Contingency ( $10 \%$ scope $+15 \%$ bid $)$
$\$ 106,723$

$\$ 60,838$

$\$ 12,940$

$\$ 252,851$

$\$ 2,028,564$

$\$ 1,550$

$\$ 2,463,465$

$\$ 615,866$ 
administration, permitting (not already provided by the construction or O\&M contractor), and legal services outside of institutional controls (e.g., licensing). Project management generally ranges from 5 to 10 percent of total construction or O\&M cost.

- Remedial Design-Includes pre-design collection and analysis of field data, engineering survey for design, treatability study (e.g., pilot-scale), and the various design components such as design analysis, plans, specifications, cost estimate, and schedule at the preliminary, intermediate, and final design phases. Remedial design costs generally range from 6 to 20 percent of the total construction cost.

- Construction Management-Includes review of submittals, design modifications, construction observation or oversight, engineering survey for construction, preparation of O\&M manual, documentation of quality control/quality assurance, and record drawings. Construction management generally ranges from 6 to 15 percent of total construction cost.

- Technical Support-Includes oversight of O\&M activities, update of O\&M manual, and progress reporting. O\&M technical support generally ranges from 10 to 20 percent of total O\&M cost.

An example of how other costs are estimated using percentages and then added to the total cost of construction activities is shown in Exhibit 8.

\section{Step 4: Present-Value Analysis}

Remedial action projects typically involve construction costs that are expended at the beginning of a project (e.g., initial capital costs) and costs in subsequent years that are required to implement and maintain the remedy after the initial construction period (e.g., annual O\&M costs, periodic costs). Present-value analysis is a method to evaluate expenditures that occur over different time periods. This standard methodology allows for cost comparisons of different remedial alternatives on the basis of a single cost figure for each alternative. This single number, referred to as the present value, is the amount needed to be set aside at the initial point

\section{Exhibit 8. Example Addition of Other Costs}

CONSTRUCTION SUBTOTAL

Contingency ( $10 \%$ scope $+15 \%$ bid)

SUBTOTAL

Project Management (5\%)

Remedial Design (8\%)

Construction Management ( $6 \%$ )

TOTAL
$\$ 2,463,465$

615,866

$\$ 3,079,331$

153,967

246,346

184,760

$\$ 3,664,404$ 
A present-value analysis involves four basic steps ... in time (base year) to assure that funds will be available in the future as they are needed, assuming certain economic conditions. The key question for the present-value analysis is:

- What is the amount of money needed to be set aside to cover estimated costs over the project duration?

A present-value analysis involves four basic steps, listed below.

\section{Define the Period of Analysis}

The period of analysis is the period of time over which present value is calculated. In general, the period of analysis should be equivalent to the project duration, resulting in a complete life-cycle cost estimate for implementing the remedial alternative. The project duration generally begins with the planning, design, and construction of the remedial alternative, continues through short- and long-term O\&M, and ends with project completion and closeout. Each remedial alternative may have a different project duration. For example, one alternative may have a two-year construction period and no future O\&M. Another alternative may have no construction period and many years of O\&M. Site-specific justification should be provided for the selected period of analysis, especially when it is less than the project duration (i.e., time required for design, construction, O\&M, and closeout).

\section{Calculate the Cash Outflows (Payments) for Each Year of the Project}

The second step of the present-value analysis is to add up the annual cash outflows for the project. These include initial capital costs to construct the remedial alternative, annual O\&M costs to operate and maintain the remedial alternative over its planned life, and periodic costs for those costs that occur only once every few years. Usually, most or all of the capital costs are expended during the construction and startup of the project, before annual O\&M begins. Although the present value of periodic costs is small for those that occur near the end of the project duration (e.g., closeout costs), these costs should be included in the present-value analysis.

Most early-phase cost analyses begin with a simplifying assumption that the duration of initial construction and startup will be less than one year (i.e., construction work will occur in "year zero" of the project). This "year zero" assumption can be modified if a preliminary project schedule has been developed and it is known that capital construction costs will be expended beyond one year.

The results of this step in the present-value analysis should be an array of all costs for each year of the project, as shown by the example in Exhibit 9.

\section{Select a Discount Rate to Use in the Present-Value Calculation}

The third step in the present-value analysis is to select a discount rate. A discount rate, which is similar to an interest rate, is used to account for the time value of money. A dollar is worth more today than in the future because, if invested in an alternative use today, the dollar could earn a 
Exhibit 9. Example Array of Costs for Present-Value Analysis

\begin{tabular}{|ccccc|}
\hline Year & Capital Costs & Annual O\&M & Periodic Costs & Total Cost (\$) \\
& $(\$)$ & Costs $(\$)$ & $(\$)$ & \\
\hline 0 & $1,800,000$ & 0 & 0 & $1,800,000$ \\
1 & 0 & 50,000 & 0 & 50,000 \\
2 & 0 & 50,000 & 0 & 50,000 \\
3 & 0 & 50,000 & 0 & 50,000 \\
4 & 0 & 50,000 & 0 & 50,000 \\
5 & 0 & 50,000 & 10,000 & 60,000 \\
6 & 0 & 50,000 & 0 & 50,000 \\
7 & 0 & 50,000 & 0 & 50,000 \\
8 & 0 & 50,000 & 0 & 50,000 \\
9 & 0 & 50,000 & 0 & 50,000 \\
10 & 0 & 50,000 & 50,000 & 100,000 \\
\hline
\end{tabular}

return (i.e., interest). Thus, discounting reflects the productivity of capital. If the capital were not employed in a specific use, it would have productive value in alternative uses. The choice of a discount rate is important because the selected rate directly impacts the present value of a cost estimate, which is then used in making a remedy selection decision. The higher the discount rate, the lower the present value of the cost estimate.

The Office of Management and Budget (OMB) Circular A-94, "Guidelines and Discount Rates for Benefit-Cost Analyses of Federal Programs," provides guidance for the use of discount rates in economic analyses performed by the federal government. The circular is available at http:// www.whitehouse.gov/OMB/circulars/a094/a094.html.

\section{Calculate the Present Value}

The last step is to calculate the present value. The present value of a remedial alternative represents the sum of the present values of all future payments associated with the project. For example, if the project will entail capital and O\&M costs each year for 12 years, the present value is the sum 
of the present values of each of the 12 payments, or expenditures.

The present value of a future payment is the actual value that will be disbursed, discounted at an appropriate rate of interest. Present value for payment $x_{\mathrm{t}}$ in year $t$ at a discount rate of $i$ is calculated as follows:

$$
P V=\frac{1}{(1+i)^{t}} \quad x_{\mathrm{t}}
$$

The first operand in this equation, $1 /(1+i)^{t}$, can be referred to as a "discount factor." Exhibit 10 illustrates the use of these factors for a remedial alternative with construction costs of $\$ 1,800,000$ in Year 0 , annual O\&M costs of $\$ 50,000$ for ten years, and periodic costs of $\$ 10,000$ in Years 5 and 10 and $\$ 40,000$ in Year 10.

Exhibit 10. Example Present-Value Calculation for a Remedial Alternative

\begin{tabular}{|c|c|c|c|c|c|c|}
\hline Year & $\begin{array}{c}\text { Capital } \\
\text { Costs (\$) }\end{array}$ & $\begin{array}{c}\text { Annual } \\
\text { O\&M } \\
\text { Costs (\$) }\end{array}$ & $\begin{array}{l}\text { Periodic } \\
\text { Costs (\$) }\end{array}$ & $\begin{array}{c}\text { Total Cost } \\
\text { (\$) }\end{array}$ & $\begin{array}{c}\text { Discount } \\
\text { Factor at } \\
7 \%\end{array}$ & $\begin{array}{c}\text { Total Present } \\
\text { Value Cost at } \\
7 \%(\$)\end{array}$ \\
\hline 0 & $1,800,000$ & 0 & 0 & $1,800,000$ & 1.000 & $1,800,000$ \\
\hline 1 & 0 & 50,000 & 0 & 50,000 & 0.935 & 46,800 \\
\hline 2 & 0 & 50,000 & 0 & 50,000 & 0.873 & 43,700 \\
\hline 3 & 0 & 50,000 & 0 & 50,000 & 0.816 & 40,800 \\
\hline 4 & 0 & 50,000 & 0 & 50,000 & 0.763 & 38,200 \\
\hline 5 & 0 & 50,000 & 10,000 & 60,000 & 0.713 & 42,800 \\
\hline 6 & 0 & 50,000 & 0 & 50,000 & 0.666 & 33,300 \\
\hline 7 & 0 & 50,000 & 0 & 50,000 & 0.623 & 31,200 \\
\hline 8 & 0 & 50,000 & 0 & 50,000 & 0.582 & 29,100 \\
\hline 9 & 0 & 50,000 & 0 & 50,000 & 0.544 & 27,200 \\
\hline 10 & 0 & 50,000 & 50,000 & 100,000 & 0.508 & 50,800 \\
\hline Total & $1,800,000$ & 560,000 & & $2,360,000$ & & $2,180,000$ \\
\hline
\end{tabular}


Exhibit 11. Example Cost Summary (1 of 2)

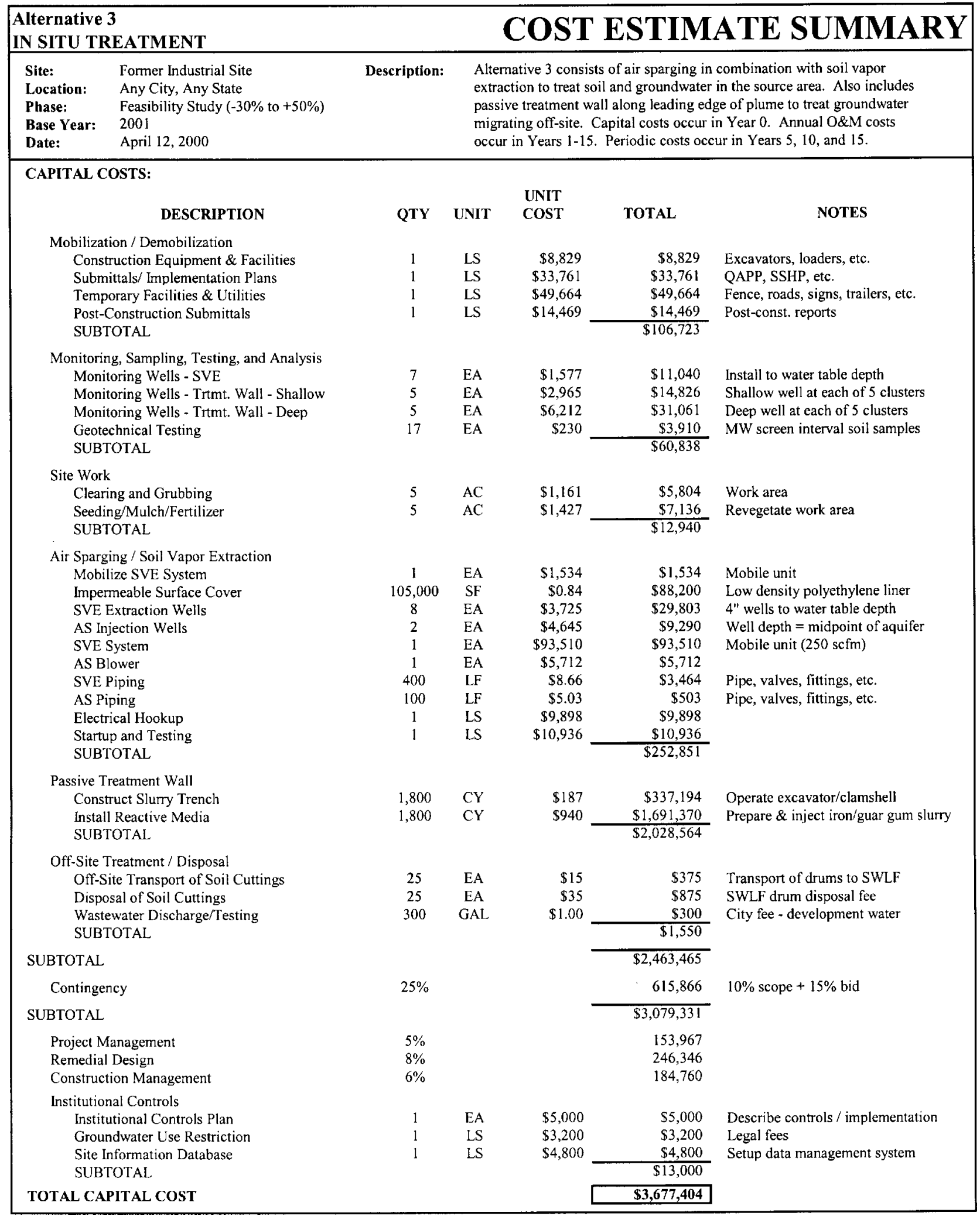


Exhibit 11. Example Cost Summary (2 of 2)

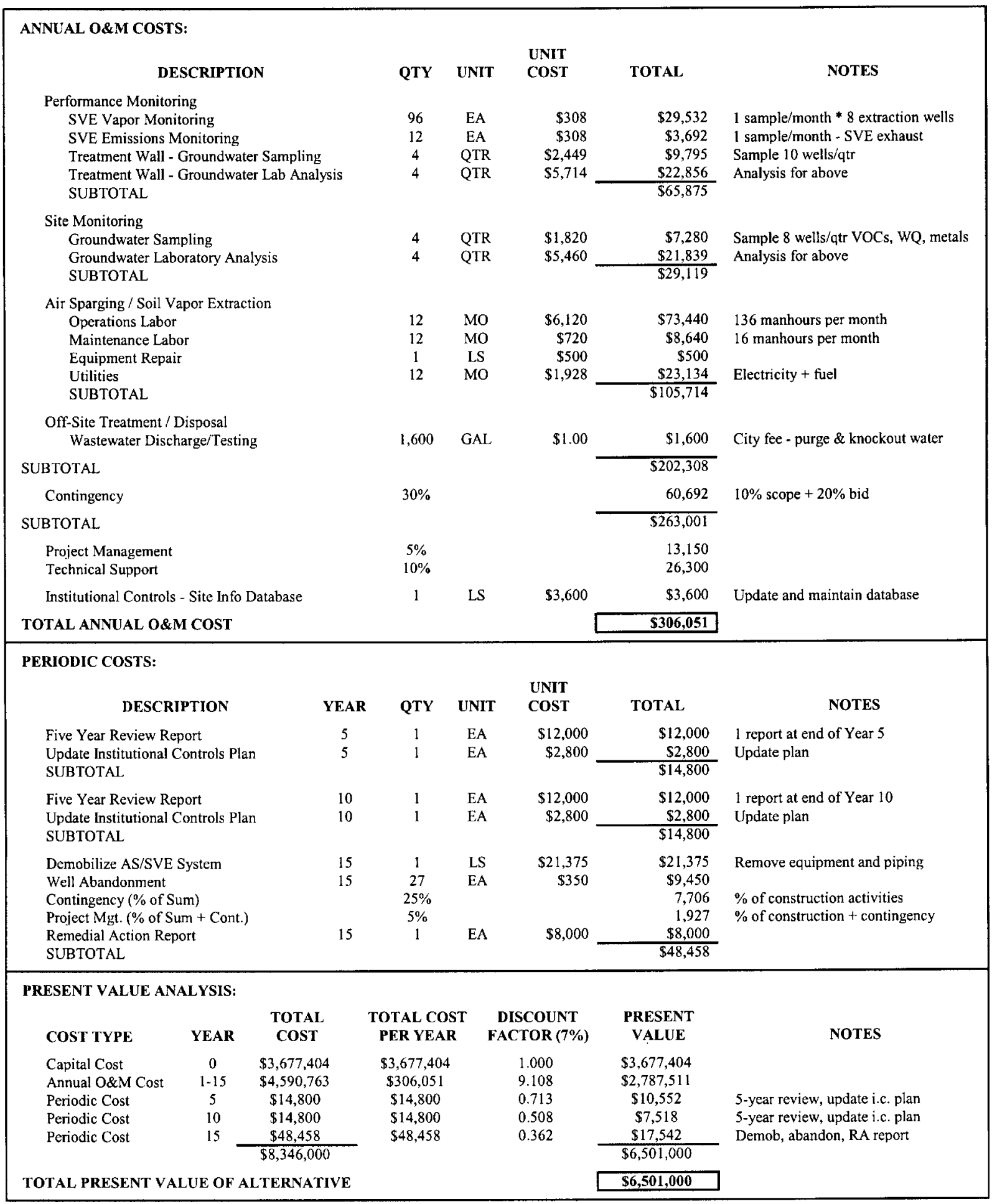


This method of present-value calculation assumes that the total expenditures for a given year occur at the beginning of that year. Thus, no interest is earned during the year on that year's funds.

\section{Step 5: Reality Check}

Now the cost estimate is complete, or is it? At this point in the process, it is important to check calculations, ensure assumptions are clearly documented, and check that nothing is missing. Questions to ask at this point include the following:

1. Has a description of the alternative been provided?

2. Have the initial, annual, and periodic activities of the alternative and associated capital and O\&M costs been identified?

3. Have quantities for activities been estimated with sufficient backup?

4. Have unit costs for activities been estimated with sufficient backup?

5. Has contingency been applied to the total of initial, annual, and periodic activities costs?

6. Have other costs been added appropriately?

7. Were guidelines followed for the present-value analysis?

8. Is there sufficient uncertainty for key factors to warrant a sensitivity analysis? If a sensitivity analysis was done, are results presented clearly in terms of total present value of the alternative?

Once the reality check is complete, a summary of the complete estimate can be generated, as shown in Exhibit 11.

\section{CONCLUSION}

Cost estimates developed during the early stages of the cleanup process are based on limited information, but are typically given significant weight in making remedy selection and other types of cleanup decisions. For this reason, it is important at this state to develop cleanup cost estimates that are as complete and accurate as possible. Using the steps provided in this paper, which follow an activity-based approach, should help achieve this goal.

\section{REFERENCE}

United States Environmental Protection Agency (USEPA). (2000, July). A guide to developing and documenting cost estimates during the feasibility study (EPA 540-R-00002). Available: http://www.epa.gov/superfund/resources/remedy/costest.htm. 